\title{
REFLEKSI POSISI PENDIDIKAN SEJARAH DALAM KEBIJAKAN KURIKULUM KURIKULUM TINGKAT SATUAN PENDIDIKAN (KTSP)
}

\author{
Adela Siahaan* dan Siti Jubaedah \\ * Pendidikan Sejarah, FKIP-UNRIKA \\ Email: delaningrat@gmail.com
}

\section{A. Abstrak}

Standar kompetensi dan kompetensi dasar menjadi arah dan landasan untuk mengembangkan materi pokok, kegiatan pembelajaran, dan indikator pencapaian kompetensi untuk penilaian. Dalam merancang program pembelajaran dan penilaian perlu memperhatikan standar proses dan standar penilaian. Untuk mencapai ke arah itu, kurikulum dan peran guru sangat menentukan keberhasilan pendidikan, karena kurikulum berjalan, sedangkan kurikulum adalah seperangkat rencana dan pengaturan mengenai tujuan, isi dan bahan pelajaran pada KTSP ada beberapa alasan yang menjadi pilihan dalam upaya perbaikan kondisi pendidikan dalam upaya perbaikan kondisi pendidikan di tanah air, salah satunya adalah potensi siswa itu berbeda-beda dan potensi tersebut akan berkembang jika stimulusnya tepat dan mutu hasil pendidikan yang masih rendah serta mengabaikan aspek-aspek moral, akhlak, budi pekerja seni dan olahraga serta life skill. Selain itu kurikulum harus mempunyai tujuan yang ingin dicapai baik yang bersifat kongkrit maupun abstrak dan berbagai konsepsinya seperti yang disebutkan di atas, sehingga hakekat kurikulum sebagai alat untuk mencapai tujuan pendidikan benar-benar terwujud.

\section{B. Pendahuluan}

Kurikulum (Nasution, 2008: 5) adalah suatu rencana yang disusun untuk melancarkan proses berlajar mengajar di bawah bimbingan dan tanggunga jawab sekolah atau lembaga pendidikan beserta staf pengajarnya. Pengertian lain disampaikan oleh Sudjana (2005: 4) bahwa kurikulum adalah niat dan rencana, proses belajar mengajar adalah pelaksanaanya. Dalam proses tersebut ada dua subjek yang terlibat yakni guru dan siswa. Siswa adalah subjek yang dibina dan guru adalah subjek yang membina. Pemberlakuan Undang-undang Republik Indonesia Nomor 32 tahun 2004 tentang Pemerintahan Daerah menuntut pelaksanaan otonomi daerah dan wawasan demokrasi dalam penyelenggaraan pendidikan berubah menjadi desentralistik. Pengelolaan pendidikan yang semula bersifat sentralistik. 
Desentralisasi pengelolaan pendidikan dengan diberikannya wewenang kepada satuan pendidikan untuk menyusun kurikulumnya mengacu pada Undang-undang Nomor 20 tahun 2003 tentang Sistem Pendidikan Nasional, yaitu pasal 3 tentang fungsi dan tujuan pendidikan nasional dan pasal 35, mengenai standar nasional pendidikan. Desentralisasi pengelolaan pendidikan yang diharapkan dapat memenuhi kebutuhan dan kondisi daerah perlu segera dilaksanakan. Bentuk nyata dari desentralisasi pengelolaan pendidikan ini adalah diberikannya kewenangan kepada satuan pendidikan untuk mengambil keputusan berkenaan dengan pengelolaan pendidikan, seperti dalam pengelolaan kurikulum, baik dalam penyusunannya maupun pelaksanaannya di satuan pendidikan. Satuan pendidikan merupakan pusat pengembangan budaya. KTSP ini mengembangkan nilai-nilai budaya dan karakter bangsa sebagai suatu kesatuan kegiatan pendidikan yang terjadi di sekolah. Nilai-nilai yang dimaksud diantaranya: religius, jujur, toleransi, disiplin, kerja keras, kreatif, mandiri demokrasi, rasa ingin tahu, semangat kebangsaan, cinta tanah air, menghargai prestasi, komunikatif, cinta damai, gemar membaca, peduli sosial dan ingkungan, serta tanggung jawab. Nilai-nilai melengkapi dan terintegrasi dalam seluruh kegiatan pendidikan sebagai budaya sekolah. Apabila melihat kaitan KTSP sebagai suatu kebijakan pendidikan, maka inilah yang coba penulis sampaikan pada tulisan ini. Adapun rumusan masalah dalam tulisan ini adalah sebagai berikut:

1. Apa pengertian kurikulum dan Kurikulum Tingkat Satuan Pendidikan (KTSP)?

2. Bagaimana Pengembangan Kurikulum Tingkat Satuan Pendidikan (KTSP)?

3. Bagaimana posisi pendidikan sejarah dalam Kurikulum Tingkat Satuan Pendidikan (KTSP)?

\section{Metodologi Penelitian}


Metode yang digunakan dalam menyelesaikan penelitian ini adalah studi literatur yaitu dengan mengumpulkan dan mengkaji berbagai sumber bacaan baik yang beruba sumber buku ataupun internet yang memuat pembahasan mengenai posisi pendidikan sejarah dalam kebijakan kurikulum tingkat satuan pendidikan (KTSP).

\section{Pembahasan}

Konsep Dasar KTSP dalam Standar Nasonal Pendidikan (SNP Pasal 1, ayat 15) dikemukakan bahwa Kurikulum Tingkat Satuan Pendidikan (KTSP) adalah kurikulum operasional yang disusun dan dilaksanakan oleh masing-masing satuan pendidikan. Penyusunan KTSP dilakukan oleh satuan pendidikan dengan memperhatikan dan berdasarkan standar kompetensi serta kompetensi dasar yang dikembangkan oleh Badan Standar Nasional Pendidikan (BSNP). Kurikulum ini mulai diberlakukan pada masa Menteri pendidikan Nasional Bambang Sudibyo. Awal 2006 ujicoba KBK dihentikan. Muncullah Kurikulum Tingkat Satuan Pendidikan (KTSP). Tinjauan dari segi isi dan proses pencapaian target kompetensi pendidikan oleh siswa hingga teknis evaluasi tidaklah banyak perbedaaan dengan Kurikulum 2004. Perbedaan yang paling menonjol adalah guru lebih diberikan kebebasan untuk merencanakan pembelajaran sesuai dengan lingkungan dan kondisi sekolah berada. Hal ini disebabkan karangka dasar (KD), standar kompetensi lulusan (SKL), standar kompetensi dan kompetensi dasar (SKKD) setiap mata pelajaran untuk setiap satuan pendidikan telah ditetapkan oleh Departemen Pendidikan Nasional. Jadi pengembangan perangkat pembelajaran, seperti silabus dan sistem penilaian merupakan kewenangan satuan pendidikan (sekolah) dibawah koordinasi dan supervisi pemerintah Kabupaten/Kota (Ismaun, 2012: 46).

Pengembangan Kurikulum Tingkat Satuan Pendidikan (KTSP) yang beragam mengacu pada standar nasional pendidikan untuk menjamin pencapaian tujuan pendidikan nasional. Standar nasional pendidikan terdiri atas standar isi, proses, kompetensi lulusan, tenaga pendidikan, sarana dan prasarana, pengelolaan, pembiayaan dan penilaian pendidikan. Dua dari kedelapan standar nasional pendidikan tersebut yaitu Standar Isi (SI), dan Standar Kompetensi Lulusan (SKL) merupakan acuan utama bagi satuan pendidikan dalam mengembangkan kurikulum. Undang-Undang Republik Indonesia No.20 Tahun 2003 (UU 20/2003) tentang Sistem Pendidikan Nasional dan Peraturan Pemerintah Republik Indonesia 
No.19 Tahun 2005 (PP 19/2005) Tentang Standar Nasional Pendidikan mengamanatkan kurikulum pada KTSP jenjang pendidikan dasar dan menengah disusun oleh satuan pendidikan dengan mengacu kepada SI dan SKL serta berpedoman pada panduan yang disusun oleh Badan Standar Nasiona Pendidikan (BSNP). Selain itu, penyusunan KTSP juga harus mengikuti ketentuan lain yang menyangkut kurikulum dalam UU 20/2003 dan PP 19/2005 (Ismaun, 2012: 47). Adapun peraturan Menteri Pendidikan Nasional Nomor 19 Tahun 2007 tentang Standar Pengelolaan Pendidikan Dasar dan Menengah menyebutkan tentang KTSP bahwa:

a. Konsep dasar KTSP. Konsep dasar KTSP meliputi tiga aspek yang saling terkait, yaitu kegiatan pembelajaran, penilaian, dan pengelolaan kurikulum berbasis sekolah.

b. Penilaian dalam KTSP. Penilaian dalam KTSP mempunyai karakteristik: dilakukan oleh guru untuk mengetahui tingkt penguasaan kompetensi ang ditetapkan yang bersifat internal, bagian dari pembelajaran, dan sebagai bahan untuk peningkatan mutu hasil belajar, berorientasi pada kompetensi, mengacu pada patokan, ketuntasan belajar, dilakukan melalui berbabagai cara yaitu: fortopolis (kumpulan kerja siswa), product (hasil karya), project (penugasan) performances (unjuk kerja), paper and pentest ( tes tulis).

c. Pengelolaan KTSP. Pengelolaan kurikulum berbasis sekolah mempunyai prinsip-prinsip: Mengacu kepada visi dan misi sekolah; Pengembangan perangkat kurikulum (silabus); Pemberdayaan tenaga kependidikan dan sumber daya lainnya untuk meningkatkan mutu hasil belajar; Pemantauan dan evaluasi.

d. Landasan kurikulum KTSP adalah sebagai berikut (Ismaun, 2012: 47):

1. Undang-Undang Republik Indonesia No.20 Tahun 2003 (UU 20/2003) tentang Sistem Pendidikan Nasional.

2. PP No.19 Tahun 2005 (PP 19/2005) Tentang Standar Nasional Pendidikan.

3. Permendiknas No.22 Tahun 2006 tentang Standar Isi.

4. Permendiknas No.23 Tahun 2006 tantang Standar Kompetensi Lulusan.

5. Permendiknas No.24 Tahun 2006 dan No.6 Tahun 2007 tentang pelaksanaan Permendiknas No.22 dan No.23 tahun 2006.

6. Permendiknas No.20 Tahun 2007 tentang Standar Penilaian Pendidikan. 
Berdasarkan pada buku yang berjudul KTSP (Kurikulum Tingkat Satuan Pendidikan): Dasar Pemahaman dan pengembangan yang ditulis oleh Masnur Muslich pada tahun 2008, yang menjadi landasan hukum KTSP adalah UU No.20 Tahun 2003, PP No.19 Tahun 2005, Permendiknas No.22 dan 23 Tahun 2006. Undang-Undang Republik Indonesia Nomor 20 Tahun 2003 tentang Sistem Pendidikan Nasional Pasal 1 ayat (19); Pasal 18 ayat (1), (2), (3), (4); Pasal 32 ayat (1), (2), (3); Pasal 35 ayat (2); Pasal 36 ayat (1), (2), (3), (4); Pasal 37 ayat (1), (2), (3); Pasal 38 ayat (1), (2). Peraturan Pemerintah Republik Indonesia Nomor 19 Tahun 2005 tentang Standar Nasional Pendidikan Pasal 1 ayat (5), (13), (14), (15); Pasal 5 ayat (1), (2); Pasal 6 ayat (6); Pasal 7 ayat (1), (2), (3), (4), (5), (6), (7), (8); Pasal 8 ayat (1), (2), (3); Pasal 10 ayat (1), (2), (3); Pasal 11 ayat (1), (2), (3), (4); Pasal 13 ayat (1), (2), (3), (4); Pasal 14 ayat (1), (2), (3); Pasal 16 ayat (1), (2), (3), (4), (5); Pasal 17 ayat (1), (2); Pasal 18 ayat (1), (2), (3); Pasal 20. Peraturan Menteri Pendidikan Nasional Nomor 22 Tahun 2006 tentang Standar Isi. Peraturan Menteri Pendidikan Nasional Nomor 23 Tahun 2006 tentang Standar Kompetensi Lulusan

Dalam Ismaun (2012: 47) Kurikulum Tingkat Satuan Pendidikan (KTSP) dikembangkan berdasarkan prinsip-prinsip sebagai berikut:

1. Berpusat pada potensi, pengembangan, kebutuhan, dan kepentingan peserta didik dan lingkungannya,

2. Beragam dan terpadu,

3. Tanggap terhadap pengembangan ilmu pengetahuan, teknologi dan seni,

4. Relevan dengan kebutuhan hidup,

5. Menyeluruh dan berkesinambungan,

6. Belajar sepanjang hayat, dan

7. Seimbang antara kepentingan nasional dan kepentingan daerah.

Dalam KTSP pendidikan sejarah diberikan untuk setiap jenjang pendidikan dasar dan menengah. Pendidikan dasar sejarah disusun berdasarkan pandangan filosofis perenialisme dengan bergabung dalam bidang studi IPS, sedangkan untuk SMA sejarah diberikan dengan filosofis esensialisme, berdiri sendiri sebagai mata pelajaran sejarah. Namun, dalam struktur programnya sejarah untuk kelas X dan kelas XI dan XII IPA hanya berbobot satu jam pelajaran per semester. Sedangkan untuk kelas XI dan XII IPS memiliki bobot tiga jam pelajaran persemester (Ismaun, 2012: 47). Dalam Standar Isi dinyatakan tentang tujuan 
kurikulum sejarah sebagai berikut: Mata pelajaran sejarah bertujuan agar peserta didik memiliki kemampuan sebagai berikut:

1. Membangun kesadaran peserta didik tentang pentingnya waktu dan tempat yang merupakan sebuah proses dari masa lampau, masa kini, dan masa depan.

2. Melatih daya kritis peserta didik untuk memahami fakta sejarah secara benar dengan berdasarkan kepada pendekatan ilmiah dan metodologi keilmuan.

3. Menumbuhkan apresiasi dan penghargaan peserta didik terhadap peninggalan sejarah sebagai bukti peradaban bangsa Indonesia di masa lampau.

4. Menumbuhkan pemahaman peserta didik terhadap proses terbentuknya bangsa Indonesia melalui sejarah yang panjang dan masih berproses hingga masa kini dan masa yang akan datang.

5. Menumbuhkan kesadaran dalam diri peserta didik sebagai bagian dari bangsa Indonesia yang memiliki rasa bangga dan cinta tanah air yang dapat diimplementasikan dalam berbagai bidang kehidupan baik nasional maupun internasional.

Standar Kompetensi Lulusan (SKL) Sejarah berdasarkan Permendiknas No 23 Tahun 2006, salah satu contohnya adalah sebagai berikut :

a. Sejarah SMA/MA kelas $\mathrm{X}$

1. Memahami ruang lingkup ilmu sejarah,

2. Menggunakan prinsip-prinsip dasar penelitian sejarah,

3. Menganalisis masa pra-aksara dan masyarakat aksara pada masyarakat Indonesia,

4. Menganalisis kehidupan awal masyarakat di Iandonesia meliputi peradaban awal, asal-usul dan persebaran manusia di wilayah nusantara/Indonesia.

\section{- Program IPA}

1. Menganalisis perkembangan masa negara-negara tradisional yang meliputi masa Hindu-Budha, Islam di Indonesia.

2. Membandingkan perkembangan masyarakat Indonesia masa penjajahan HindiaBelanda dan Pemerintahan Pendudukan Jepang.

3. Menganalisis proses kelahiran dan pertumbuhan nasionalisme di Indonesia.

4. Merekonstruksi perkembangan masyarakat Indonesia sejarah Proklamasi Kemerdekaan sampai dengan Demokrasi Terpimpin. 
5. Merekontruksi pergantian pemeritahan masa awal kemerdekaan (1945-1955), Demokrasi Terpimpin (1955-1967), ke masa pemerintahan Orde Baru (1967-1998) sampai periode Reformasi (Sejak 1998 s/d sekarang).

6. Merekonstruksi perkembangan masyarakat pada masa Orde Baru.

7. Menganalisis perkembangan ilmu pengetahuan dan teknologi sesudah Perang Dunia II sampai dengan pertumbuhan teknologi mutakhir.

- Program IPS

1. Menganalisis kehidupan awal, peradaban manusia Indonesia dan bangsa-bangsa lain di dunia, serta asal-usul dan persebaran manusia di Indonesia.

2. Menganalisis perkembangan bangsa Indonesia pada masa negara tradisional, meliputi perkembangan budaya, agama, dan sistem pemarintahan masa HinduBudha, masa Islam, proses interaksi antar tradisi lokal, Hindu-Budha dan Islam Indonesia.

3. Menganalisis kesejahteraan masa kolonial Hindia-Belanda (pengaruh Barat) meliputi perbahan ekonomi, demografi, sosial, serta politk dan masa kolonial Jepang yang meliputi perubahan sosial-ekonomi-politik.

4. Menganalisis pengaruh berbagai revolusi politik dan sosial di dunia (Revolusi Perancis, Revolusi Amerika, Revolusi Rusia) terhadap perubahan sosial, ekonomi, dan politik di Indonesia.

5. Menganalisis peristiwa sekitar Proklamasi 17 Agustus 1945, terbentuk Negara Kesatuan Republik Indonesia dan lahirnya UUD 1945.

6. Menganalisis perkembangan masyarakat Indonesia mulai masa kerajaan-kerajaan Hindu-Budha, Kerajaan-kerajaan Islam, pemerintahan kolonial Belanda, Inggris, pemerintahan pendudukan Jepang, meliputi politik (lahirnya gerakan pendidikan dan nasionalisme), cita-cita terbentuknya negara merdeka dan sebagainya.

7. Menganalisis perjuangan dalam mempertahankan kemerdekaan dan persatuan NKRI dari ancaman disintegrasi bangsa, antara lain peristiwa Madiun 1948, pemberontakan DI/TII, peristiwa Andi Aziz, RMS, PRRI, dan gerakan G30-S/PKI.

8. Menganalisis perkembangan masyarakat Indonesia sejak Proklamasi sampai dengan masa Orde Baru, dan masa Reformasi, meliputi masa pemerintahan Demokrasi 
Terpimpin (Orde Baru, 1945-1967), masa Demokrasi Pancasila (Orde Baru, 1967-1998)

dan masa peralihan ke masa Reformasi (1998-sekarang).

- $\quad$ Program Bahasa

1. Menganalisis kehidupan masyarakat Indonesia periode kerajaan-kerajaan tradisional, yang meliputi masa kerajaan Hindu-Budha dan Islam .

2. Menganalisis perkembangan bahasa dan karya sastra masa kebudayaan HinduBudha dan Islam.

3. Menganalisis perkembangan masyarakat dan bahasa, karya sastra masa pemerintahan kolonial Belanda.

4. Menganalisis proses kelahiran dan perkembangan nasionalisme di Indonesia

5. Merekontruksi perkembangan masyarakat Indonesia periode Proklamasi (19451955), Orde Lama (1955-1967), Orde Baru (1967-1998) dan Reformasi (1998 sampai sekarang), meliputi perkembangan politik, ekonomi, sosial, budaya, bahasa dan karya sastra.

Berdasarkan Permendiknas tersebut di atas dapat kita lihat bahwa muatan yang terkandung di dalam SKL sangat banyak dan padat. Materi pelajaran yang harus di sajikan tidak sebanding dengan waktu yang disediakan. Itulah salah satu kelemahan SKL yang disusun oleh Badan Standar Nasional Pendidikan (BSNP) yang kiranya perlu revisi dan penyesuaian. Kelemahan lain yang ada pada SKL adalah bahwa materi-materi pelajaran yang harus dikuasai terlepas antara satu dengan materi yang lain, hal ini bertentangan dengan prinsip sejarah yang kontinuitas, kronologis, dan kausalitas, satu peristiwa selalu berkaitan dengan peristiwa lain atau suatu peristiwa menimbulkan peristiwa lainnya. Sehingga peristiwa-peristiwa yang menjadi materi pokok sejarah terputus, hal ini disebabkan materi dipilih-pilih sesuai dengan kebutuhan (Ismaun, 2012:50). 


\section{E. Daftar Pustaka}

Ismaun. 2012. Hand Out Mata Kuliah: Kebijakan-kebijakan Pemerintah dalam Pendidikan Sejarah. Bandung: Program Studi Pendidikan Sejarah, Sekolah Pasca Sarjana Universitas Pendidikan Indonesia

Muslich, Masnur. 2008. KTSP (Kurikulum Tingkat Satuan Pendidikan): Dasar Pemahaman dan pengembangan. Jakarta: Bumi Aksara.

Nasution, S. 2008. Kurikulum dan Pengajaran. Jakarta: Bumi Aksara.

Sudjana, Nana. 2005. Pembinaan dan Pengembangan Kurikulum di Sekolah. Jakarta: Sinar Baru Algesindo. 